\title{
電気二重層キャパシタ構成材料
}

\section{Structural Members for Electric Double Layer Capacitors}

成 瀬 新 二

\section{第 1 節 アラミドセパレータ}

1.はじめに

自動車業界では大気污染、地球温暖化、石油などの化石 燃料枯渇問題により、ハイブリッド車、燃料電池車が登場 し、その駆動用電源として電池、電気二重層キャパシタ(以 下キャパシタ)が使用されるようになったが、従来の電池 では出力密度が小さく、その蓄電したエネルギーを十分に 活用できているとは言い難い。また、キャパシタに関して は出力密度は大きいが、エネルギー密度が小さいため、サ イズ、重量が大きくなってしまうという課題があり、実用 化されているのは電池が主となっている。現状でも低公害 化の効果はあるが、さらなる燃費の向上のニーズに対応し て、性能の改善が進められている。特にトラックやバスな どの大型商用車は駆動に要する出力が大きいこと、及びブ レーキング時の回生エネルギーが大きいことから、電池で は対応できず、キャパシタが採用されているが、まだサイ ズ、重量が大きく、さらなる小型化、軽量化が強く求めら れている。

キャパシタの小型化、軽量化の実現に向け、主に電極、 電解液の開発が進められているが、このたび当社開発のセ パレータを使用し、キャパシタ製造工程中の活性炭電極と セパレータを組み合わせたいわゆる電極ユニットの状態で の乾燥温度を大幅に上昇させることによって、キャパシタ の耐電圧の向上に成功した。

\section{2. アラミドセパレータの特徵}

\section{1 アラミド}

アラミドとは、aromatic polyamide(芳香族ポリアミド) の意で脂肪族ポリアミド(いわゆる “ナイロン”類) と対比 される。アラミドは、「アミド結合を介して結びついた芳 香族基からなる合成線状高分子で、アミド結合の $85 \%$ 以 上が 2 個の芳香環と直接接しており、アミド基の $50 \%$ 以

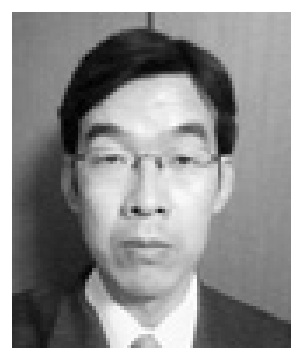

SHINJI NARUSE

デュポン帝人アドバンスドペーパー侏 シニア・リサーチ・エンジニア 東京大学農学系研究科修士課程卒 干100-6111 東京都千代田区永田町 211-1 山王パークタワー

Tel : 03-5521-2813 Fax : 03-5521-2825 E-mail ; shinji.naruse@jpn.dupont.com 〈専門〉アラミドシート研究・開発 〈趣味〉スポーツ観戦
下がイミド基で置換されていてもよい」と定義される (ISO 2076-1977)。

アラミドはアミド基の結合位置により通常メタ型とパラ 型に分類される ${ }^{1)}$ 。

\section{2 アラミドセパレータ}

アラミドセパレータとはアラミドを多孔質シート化した ものであり、特に当社が開発したセパレー夕は、100\%ア ラミド素材により構成されるので、図 1 に示すように、 150 $\sim 350^{\circ} \mathrm{C}$ で各 45 分加熱しても、収縮率が $\pm 0.3 \%$ 以内と寸 法安定性が非常に高い。

また、図 2 は、150 $350^{\circ} \mathrm{C}$ で各 45 分加熱した後のセパ レー夕に電解液を含浸し、内部抵抗を測定した結果である が、加熱前の值と比較して、同等の值であり、加熱処理に より、セパレータの細孔のサイズが変わらないことを示し ている。このことから、当社開発のセパレー夕を使用した キャパシタは高温で使用してもセパレー夕の変形による特 性の変化は発生しないと考えられる。

さらにアラミドに含まれるアミド結合の炭素と酸素の二 重結合部分は通常のキャパシタの電解液に用いられるカー

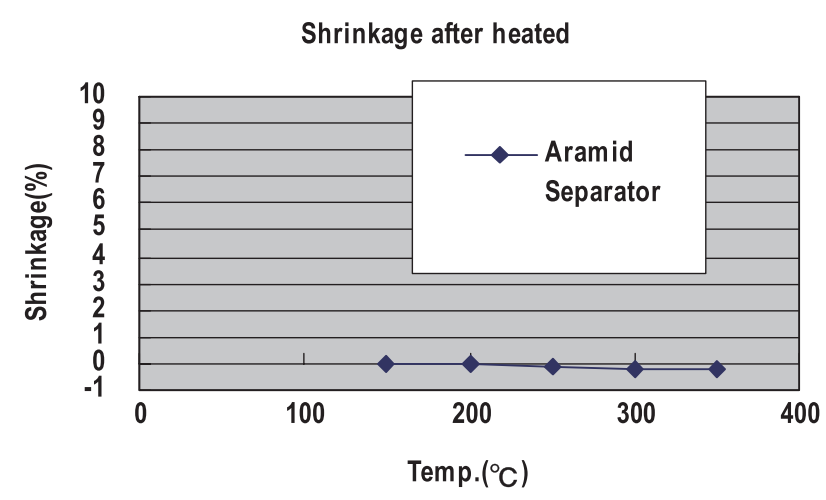

図 1 加熱収縮率

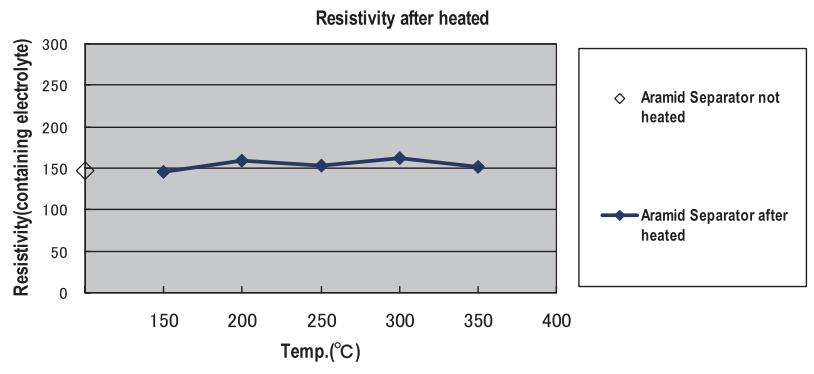

図 2 加熱後内部抵抗 
ボネート系溶媒中にも存在するため、カーボネート系溶媒 に対する当社開発セパレータの濡れ性は非常に高くなって いる。このことからカーボネート系溶媒を電解液として使 用するキャパシタに当社開発のセパレータを使用した場合、 低温特性が良くなると考えられる。

\section{3. 電気二重層キャパシタ}

\section{1 電気二重層キャパシタ}

電気二重層キャパシタとは、電解液に 1 対の導体を浸し て正負の電圧を加えると、電解液と導体の界面に自然に生 じる 1 分子の薄膜をはさんで導体側に電荷あるいはホール、 電解液側にはそれとは反対の極性のイオンが互いに引き付 けられて蓄電するデバイスである2)。

\section{2 キャパシタの構造}

通常導体としてょく使用される活性炭電極をアルミ集電 極の両面および／または片面に、塗布または接着し、セパ レータと交互に積層または捲回し、ケースに挿入し、電解 液に浸し、封口した構造となっている。

\section{3 キャパシタの特性}

キャパシタに加える電圧を高めていくとある特定の電圧 で電気分解が始まるため、通常それより低い電圧範囲で使 用される。通常よく使用されるプロピレンカーボネートに 4 級アンモニウム塩を溶解した電解液と活性炭の組み合わ せでは耐電圧は $2.3 \sim 2.5 \mathrm{~V}$ と言われている。また、キャパ シタは二次電池と比較して出力密度は高いが、エネルギー 密度が低いことが課題であった。

\section{4. アラミドセパレータの電気二重層キャパシタへの応用例}

\section{1 活性炭吸着水}

当社ではキャパシタの耐電圧を向上させる手段として活 性炭を高温で乾燥することにより、活性炭の表面に物理吸 着、化学吸着していると考えられる水分が除去されると考 え、乾燥温度と活性炭水分率の関係を測定した。図 3 に示 すように各温度で真空乾燥 12 時間行った場合、乾燥温度 と水分除去量には強い相関関係が見られた。

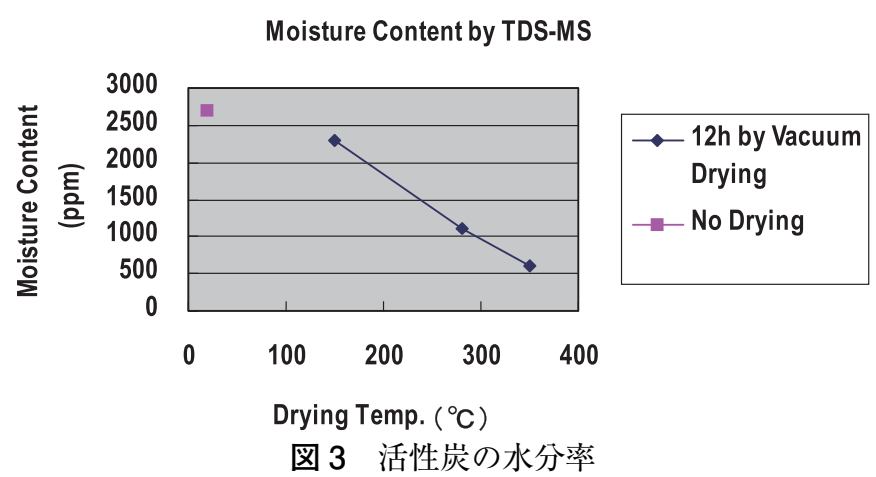

\section{2 電極ユニットの乾燥}

活性炭は吸着性が非常に強いため、活性炭単体で乾燥し
てもその後の製造工程中に水分を吸着する可能性があり、 電極、集電極、セパレータからなる電極ユニットを電解液 に浸す直前に乾燥するのが好ましいと考えられている。従 来この電極ユニットの乾燥温度はセパレータとして使用さ れているセルロースの耐熱性の問題から $150^{\circ} \mathrm{C}$ くらいが上 限とされていた。今回、当社ではアラミドセパレータを使 用することで電極ユニットを $280^{\circ} \mathrm{C}$ で乾燥したキャパシタ を作製し、セルロースセパレータを使用し、 $150^{\circ} \mathrm{C}$ で乾燥 したキャパシタと比較した。

\section{3 耐電圧の評価}

キャパシタのフロート特性(満充電の状態でキャパシタ を保持)を測定することにより、耐電圧を評価した。図 4 、 図 5 示すように重要特性である容量維持率、抵抗変化率に 乾燥温度の差が明確に現れた。これは、電極ユニットの乾 燥温度が高いと活性炭中の水分が除去され、水分による電 解液の分解、あるいは水分自身の電気分解による水素など のガスの発生が抑制されたことによると考えられる。

\section{5. まとめ}

以上の結果から、当社開発のアラミドセパレータを電気 二重層キャパシタに適用した場合、

1）電気二重層キャパシタの電極、集電極、当社開発のア ラミドセパレータからなる電極ユニットを電解液に浸 す直前に高温で乾燥することにより、耐電圧の向上が

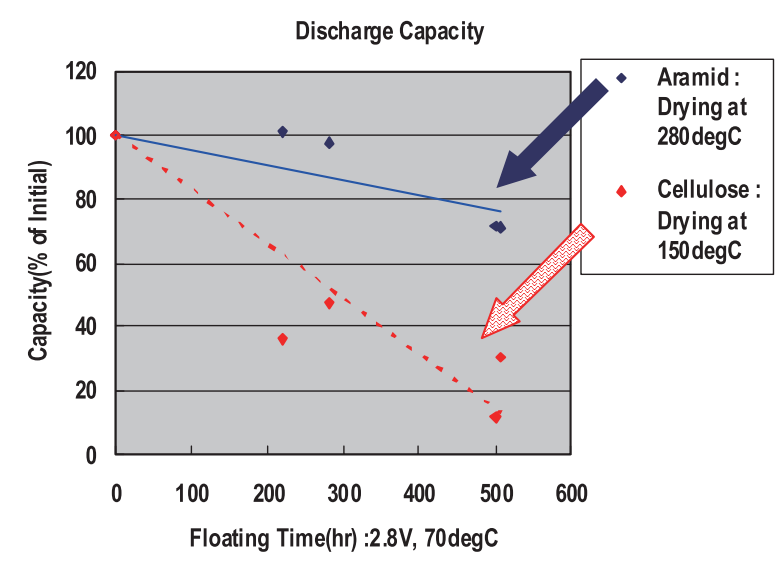

図 4 フロート試験(容量維持率)

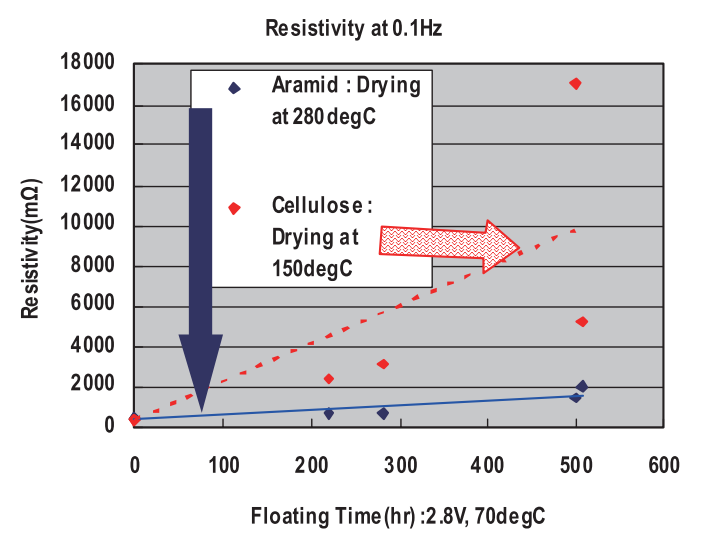

図 5 フロート試験(抵抗) 
見られた。

2）耐電圧が向上したことにより、エネルギー密度、出力 密度も向上し、電気二重層キャパシタの小型化・軽量 化の実現が期待できる。

3）今回の適用では電極のバインダーにPTFE (polytetrafluoroethylene)を使用したため、電極ユニット の乾燥温度が $280^{\circ} \mathrm{C}$ であったが、当社が展開中である アラミドバインダーを適用すれば、 $350^{\circ} \mathrm{C}$ の乾燥が可 能となり、図 3 からもさらなる水分率の低下による性 能の向上が見込まれる。

4）高温での寸法変化、孔のサイズの変化がほとんどない ので、高温で使用可能なキャパシタが期待できる。

5）アラミドはカーボネート系電解液との濡れ性が良いの で、低温特性の向上が期待できる。

\section{第 2 節 アラミドバインダー}

\section{1. はじめに}

高耐熱アラミドバインダーの特徴及びそれを第 1 節で紹 介した $100 \%$ アラミド素材よりなる高耐熱セパレータとの 組み合わせで電気二重層キャパシタに適用した例を報告す る。

\section{2. アラミドバインダーの特徵}

バインダーとは電極活物質、導電助剤を結着し、シート 化を可能にする物質で、キャパシタ向けバインダーとして はフィブリル状のポリ四フッ化エチレン (PTFE: polytetrafluoroethylene)、ガム状のポリフッ化ビニリデン (PVdF : poly-vinylidene fluoride)、点結着のエラストマー (例 SBR : styrene-butadiene rubber)などがあるが、この たび耐熱性の高いアラミドをバインダーとして適用した。 特徵としては耐熱性が高いこと以外にも、PVdF と同じ溶 剂溶解型であるため塗工性に優れ、薄い電極シートの作製 が容易であることなどが挙げられる。当社は特に長期耐熱 性の高いメタ型アラミドの一種である MPIA (poly-mphenylene isophthalamide)をバインダーとして適用した。 アラミドバインダーの結着力は同じ溶剤溶解型の PVdF と比較すると図 6 (集電䈃なしの電極シートで引張強度を 測定)に示すようにかなり高い。このことから、少ない使

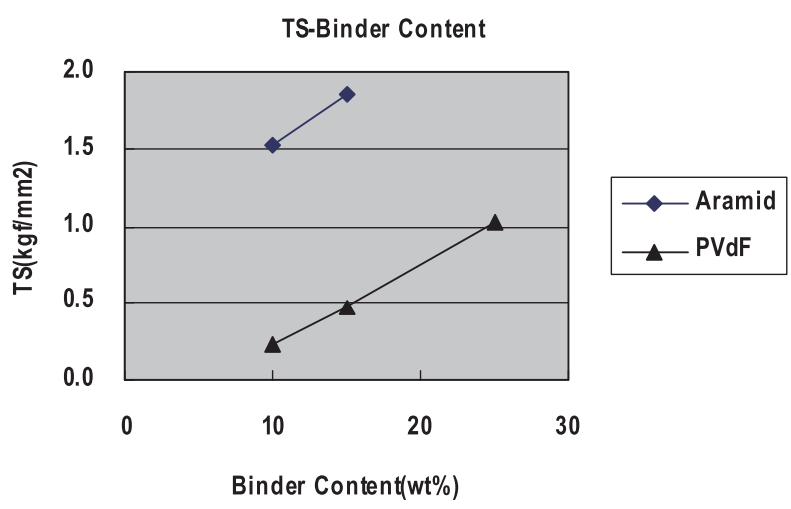

図 6 電極シート引張強度
用量で電極シートを作製可能で、キャパシタの容量向上、 低抵抗化などが期待できる。

\section{3. アラミドバインダーの電気二重層キャパシタへの応用例 3.1 加熱処理}

アラミドバインダーの結着機構は、図 7 に示すように同 じ溶剂溶解型バインダーである PVDF と同じガム状であ るが、 $350^{\circ} \mathrm{C}$ で加熱することにより、図 8 示すように、点 結着に近い構造に変化した。また、図 9 に活性炭／アラミ ドバインダー $=85 \mathrm{wt} \% / 15 \mathrm{wt} \%$ の電極シートを加熱処理し たときの、加熱処理温度と体積抵抗の関係を示したが、熱 処理温度が高くなると体積抵抗率が小さくなる傾向が見ら

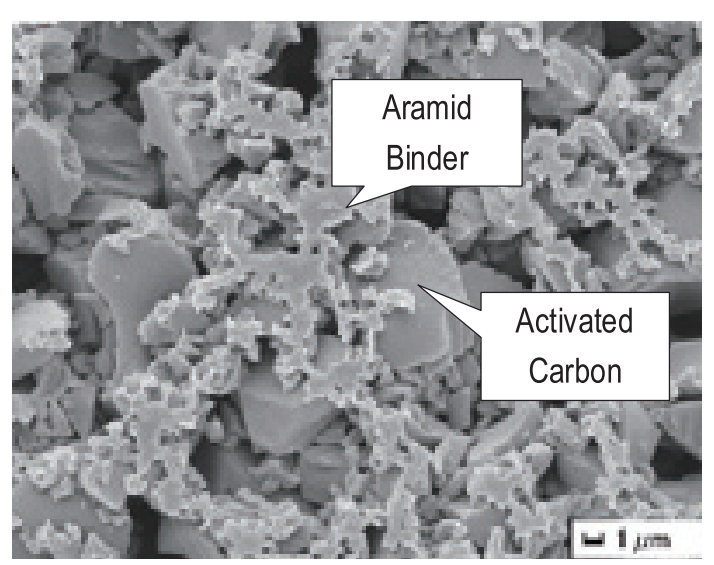

図 7 電極シート SEM 写真 $\left(350^{\circ} \mathrm{C}\right.$ 加熱前 $)$

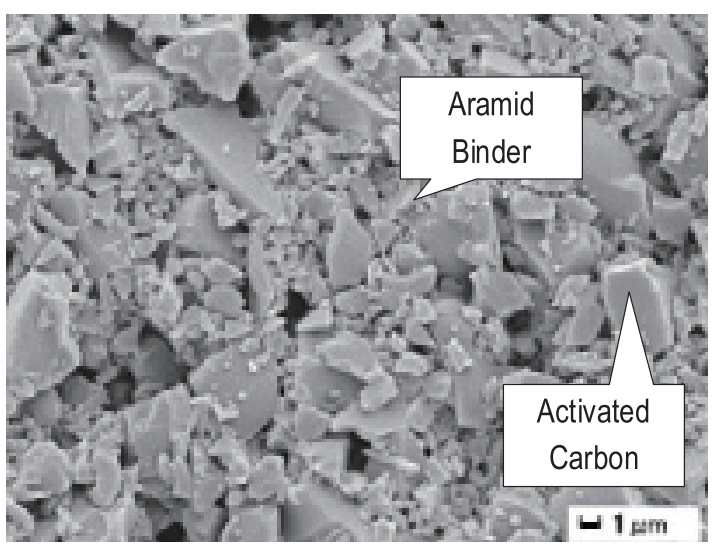

図 8 電極シート SEM 写真 $\left(350^{\circ} \mathrm{C}\right.$ 加熱後)

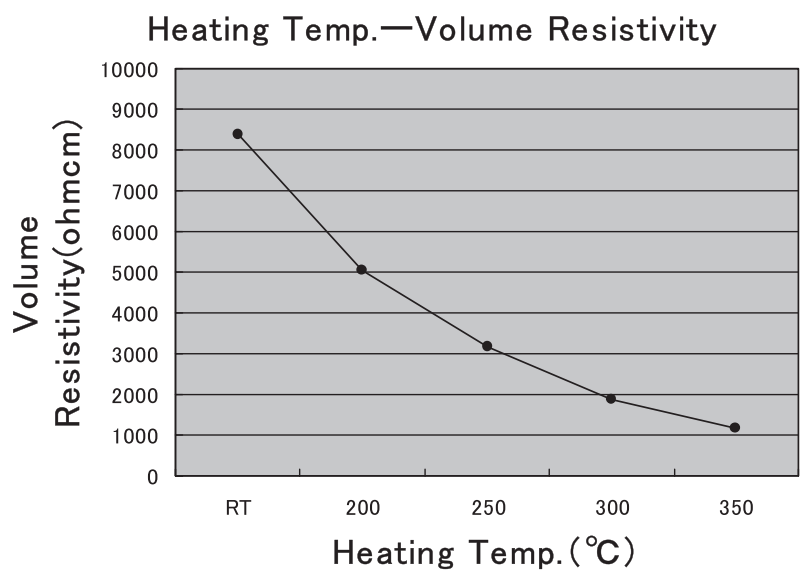

図 9 加熱処理温度と体積抵抗 
表 1 初期特性

\begin{tabular}{|c|c|c|c|c|c|c|}
\hline \multirow{3}{*}{$\begin{array}{c}\text { Drying } \\
\text { Temp. } \\
\left({ }^{\circ} \mathrm{C}\right)\end{array}$} & \multicolumn{6}{|c|}{ Initial $\left(25^{\circ} \mathrm{C}\right)$} \\
\cline { 2 - 7 } & \multicolumn{2}{|c|}{ Discharged Capacity } & \multicolumn{4}{c|}{ Resistivity } \\
\cline { 2 - 7 } & $\mathrm{mAh}$ & $\%$ of Charged & $\mathrm{m} \Omega$ & $\%$ of $150^{\circ} \mathrm{C}$ & $\mathrm{m} \Omega$ & $\%$ of $150^{\circ} \mathrm{C}$ \\
\hline 350 & 3.06 & 93.32 & 156 & 78 & 343 & 67 \\
\hline 150 & 3.10 & 77.25 & 201 & 100 & 501 & 100 \\
\hline
\end{tabular}

表 2 低温特性

\begin{tabular}{|c|c|c|c|c|c|c|}
\hline \multirow{3}{*}{$\begin{array}{c}\text { Drying } \\
\text { Temp. } \\
\left({ }^{\circ} \mathrm{C}\right)\end{array}$} & \multicolumn{6}{|c|}{ Low Temp $\left(-30^{\circ} \mathrm{C}\right)$} \\
\cline { 2 - 7 } & \multicolumn{2}{|c|}{ Discharged Capacity } & \multicolumn{4}{c|}{ Resistivity } \\
\cline { 2 - 7 } & $\mathrm{mAh}$ & $\%$ of Charged & $\mathrm{m} \Omega$ & $\%$ of $150^{\circ} \mathrm{C}$ & $\mathrm{m} \Omega$ & $\%$ of $150^{\circ} \mathrm{C}$ \\
\hline 350 & 3,034 & 98.4 & 753 & 87 & 2557 & 38 \\
\hline 150 & 2.952 & 95.0 & 867 & 100 & 6741 & 100 \\
\hline
\end{tabular}

れた。電極シート成形可能で、結着力が十分にあるならば、 点結着構造のほうが、キャパシタ特性が高くなることが期 待できるため、 $350^{\circ} \mathrm{C}$ 加熱処理した電極ユニット (電極シー トとセパレータの組み合わせ) と $150^{\circ} \mathrm{C}$ 加熱処理の電極ユ ニットを使用したキャパシタの特性比較を行った。

\section{2 キャパシタの特性}

$350^{\circ} \mathrm{C}$ で加熱処理した電極ユニットを使用したキャパシ 夕は $150^{\circ} \mathrm{C}$ 加熱処理と比較して、表 1 に示すように、充放 電効率が高い、抵抗が低い、また、レート特性が高い、自 己放電特性が高いなどの大きな効果をもたらした。さらに、 その効果は表 2 に示すように、 $-30^{\circ} \mathrm{C}$ の低温でも発現し た。これは、主に(1)バインダーの $350^{\circ} \mathrm{C}$ 加熱による収縮に より電解液中のイオンの移動路が拡張したこと、(2) $350^{\circ} \mathrm{C}$ が MPIAの結晶化温度近辺であることからバインダーそ のものの強度が向上し、高結着力が発現したことによると 考えられる。

\section{4. まとめ}

以上の結果から、結論をまとめると次のとおりである。

1）アラミドバインダーは結着力が高く、少ない使用量で
電極シートを作製可能で、キャパシタの容量向上、低 抵抗化などが期待できる。

2) アラミドバインダーを使用した電気二重層キャパシタ の電極を加熱処理することにより、アラミドバイン ダーの形状変化、及びキャパシタの特性向上が見られ た。

3）第 1 節で報告したアラミドセパレータとの組み合わせ で、加熱処理と電極ユニットの乾燥を兼ねることが可 能で、工程の短縮化、耐電圧の向上によるエネルギー 密度、出力密度の向上、さらには電気二重層キャパシ 夕の小型化・軽量化の実現が期待できる。

4）第 1 節で報告したアラミドセパレータとの組み合わせ で、高温で使用可能なキャパシタが期待できる。

5）アラミドはカーボネート系電解液との濡れ性が良いの で、低温特性の向上が期待できる。

\section{文 献}

1）中石昭夫 :「アラミド不織布の技術開発動向」, エレク トロニクス実装学会誌, Vol.4, No.2, pp.119, 2001

2) 岡村廸夫 :「電気二重層キャパシタと蓄電システムー 第 3 版 - 」, 日刊工業新聞社, pp. 9-12, 2005 